\title{
ENFORCEMENT OF FAIR-TRADE LAWS IN NON-FAIR-TRADE JURISDICTIONS
}

The legal structure of resale price maintenance is fundamentally an authorization to violate antitrust laws running from the federal government through the states to manufacturers who wish to establish a retail price level for their products. Congress first gave to the states the privilege of passing laws which, without congressional approval, would have been contrary to the Sherman Act if applied to interstate commerce. ${ }^{1}$ Then state legislatures gave to manufacturers the privilege of entering into contracts with wholesalers and retailers which without state approval would have been violative of state antitrust laws. ${ }^{2}$ In addition, the states have given to any injured party the right to enforce fair-trade prices against anyone who knowingly violates the established price even though the violator may not have signed a fair-trade agreement. ${ }^{3}$

Under the protective mantle of the Miller-Tydings Amendment to the Sherman Act ${ }^{4}$ forty-five states passed fair-trade laws. ${ }^{5}$ After the Supreme Court had held that it was constitutional to enforce a fair-trade contract against a nonsigner, ${ }^{6}$ there seemed little that could legally shake fair trade. However, in 1951 the Supreme Court discovered by carefully reading the Miller-Tydings Amendment that only the interstate enforcement of contracts and agreements between signers was authorized, and accordingly enforcement against a nonsigner across state lines was contrary to the Sherman Act and unlawful. ${ }^{7}$ Shortly before this decision the Third Circuit had uncovered another flaw in the federal law. ${ }^{8} \mathrm{~A}$ mail-order house in Pennsylvania had been selling Sunbeam electric shavers at less than fair-trade prices throughout the country. The court was willing to grant an injunction against sales in Pennsylvania but declined to extend that relief to the other states on the theory that to do so would create an undue burden on interstate commerce.

To fill these two gaps, Congress in 1952 enacted the McGuire Amendment to the Federal Trade Commission Act. ${ }^{9}$ It specifically provided that

${ }^{2}$ Dr. Miles Medical Co. v. John D. Park and Sons Co., 220 U.S. 373 (1911). 26 Stat. 209 (1890), 15 U.S.C.A. \$ 1 (1951).

${ }^{2}$ Consult 1 CCH Trade Reg. Rep. $\$ 3075$.

${ }^{3}$ Consult ibid., at 13250.

450 Stat. 693 (1937), 15 U.S.C.A. $\$ 1$ (1951).

${ }^{5}$ The exceptions are Missouri, Texas, Vermont, and the District of Columbia.

${ }^{\circ}$ Old Dearborn Distributing Co. v. Seagram-Distillers Corp., 299 U.S. 183 (1936). Consult Fulda, Resale Price Maintenance, 21 U. of Chi. L. Rev. 175 (1954).

'Schwegmann Bros. v. Calvert Distillers Corp., 341 U.S. 384 (1951).

${ }^{8}$ Sunbeam Corp. v. Wentling, 185 F. 2d 903, modified on rehearing, 192 F. 2d 7 (C.A. 3d, 1951).

๑ 66 Stat. 632 (1952), 15 U.S.C.A. $\$ 45$ (Supp., 1953). 
enforcement of fair-trade prices against nonsigners engaged in interstate commerce would not violate the antitrust laws or the Federal Trade Commission Act and further provided that:

Neither the making of contracts or agreements ... nor the exercise or enforcement of any right or right of action ... shall constitute an unlawful burden or restraint upon, or interference with, commerce.10

To circumvent this provision and the state fair-trade laws, a mail-order house might be established in a non-fair-trade jurisdiction to send goods at less than fair-trade prices into fair-trade states. ${ }^{11}$ This comment will explore some of the problems which would face a manufacturer who wishes to enforce fair-trade laws against such a mail-order house.

The manufacturer's major obstacle is that he must enter the non-fairtrade jurisdiction and persuade a court there to apply a foreign fair-trade law. The general rule with respect to torts is that "the law of the place of wrong determines whether a person has sustained a legal injury,"12 and, "if a cause of action in tort is created at the place of wrong, a cause of action will be recognized in other states." ${ }^{\prime 13}$ The manufacturer must first, therefore, convince the court that a tort has been committed within a fairtrade jurisdiction.

The state fair-trade laws make "advertising, offering for sale, or selling"14 commodities at less than fair-trade prices unfair competition. Of the three, it would be easiest to prove that advertising had occurred inside the fair-trade jurisdiction. Probably an extensive mail-order business would be impossible without the use of some form of interstate advertising. An injunction against advertising goods at less than fair-trade prices in fair-trade jurisdictions might, therefore, be sufficient to block successful operation of the mail-order house.

It would be more difficult to show that an offering for sale had occurred in the foreign jurisdiction. The word offer suggests the law of contracts; a mail-order house could probably avoid making contractual offers outside its own jurisdiction. A statement that all orders were subject to acceptance at the home office would probably suffice to convert any solicitations into

${ }^{20}$ Ibid.

${ }^{11}$ This was suggested by the activities of one Masters Corp., described in: Wall Street Journal, p. 1, col. 6 (September 23, 1954); General Electric Co. v. Masters, Inc., 307 N.Y. 229, 120 N.E. 2d 802 (1954); and General Electric Co. v. Masters Mail Order Co., 122 F. Supp. 797 (S.D. N.Y., 1954). As yet Masters has not directly presented the problem to be considered here because, although operating a store in the District of Columbia, a non-fair-trade jurisdiction, they have maintained an office in New York City and were first incorporated in Maryland, both fair-trade jurisdictions.

${ }^{12}$ Rest., Conflict of Laws $\$ 378$ (1934).

${ }^{13}$ Ibid., at $\$ 384(1)$.

${ }^{14}$ Consult 1 CCH Trade Reg. Rep. 3075. 
advertising, making the customer's order the offer and the shipment the acceptance. ${ }^{15}$ The use of the word offer, however, in these statutes does not compel the use of contract analysis; the phrase could be construed to mean any type of solicitation. But if the state legislatures intended the word offer to have such a broad meaning, they need not have included the category of advertising in the list of actionable violations.

Like offering for sale, selling immediately suggests the terminology of the law of sales and more particularly the concept of passage of title. By careful legal planning the mail-order house could probably arrange the transaction so that title would pass when the goods were delivered to the carrier inside the non-fair-trade jurisdiction. ${ }^{16}$ Use of the passage-of-title concept to determine the location of the sale seems an undue restriction on "selling" in this context. It could be plausibly argued that the evil to be prevented by fair-trade laws is that of giving purchasers an opportunity to get fairtraded items at less than the fair-trade price. If the purchaser is the significant party, it would seem to follow that anyone providing an opportunity to buy at less than fair-trade prices would be guilty of unfair competition in the jurisdiction of the purchaser.

Even if the manufacturer persuades the court that a tort has been committed inside a fair-trade jurisdiction, the court still may refuse to apply the law of that state to the transaction. No precedents applying the rule that the law of the place of wrong governs foreign fair-trade violations have been found; good analogies are scarce because of the peculiar nature of this statutory tort. First, the tort is of a multiple character-the activities of the mail-order house presumably give rise to a cause of action in every fair-trade jurisdiction in which it advertises or into which its goods are shipped. In this respect it is similar to defamation, which in theory can create a separate cause of action in each jurisdiction in which the defamatory statement is published. ${ }^{17}$ The remedy, however, distinguishes the two torts: for defamation the cure is damages; for unfair competition the usual remedy is an injunction. The only other tort which may be analogous is the common-law tort of unfair competition, which typically is passing off goods under the name of another producer. ${ }^{18}$ The common-law tort of unfair competition, like its statutory cousin, is potentially multiple in that a cause

2x 1 Corbin, Contracts $\$ 88$ (1950).

${ }^{10}$ See General Electric Co. v. Masters Mail Order Co., 122 F. Supp. 797 (1954).

${ }^{17}$ For a discussion of the multiple-tort problem with emphasis on defamation, consult Leflar, Choice of Law: Torts: Current Trends, 6 Vand. L. Rev. 447 (1953), and The Choice of Law in Multistate Defamation and Invasion of Privacy: an Unsolved Problem, 60 Harv. L. Rev. 941 (1947). See note 27 infra.

\footnotetext{
${ }^{18}$ For a discussion of the conflict-of-laws problems associated with unfair competition, consult The Choice of Law in Multistate Unfair Competition: A Legal-Industrial Enigma, 60 Harv. L. Rev. 1315 (1947), and cases collected in 148 A.L.R. 139 (1944).
} 
of action is created in every jurisdiction in which the goods are sold; in addition, injunctive relief is common to both.

As a practical matter the action against the hypothetical mail-order house will probably be brought in the federal courts. ${ }^{19}$ Therefore, the closest conflict-of-laws analogy available will be a common-law action to restrain unfair competition in interstate trade brought in the federal courts on the basis of diversity of citizenship. What law has been applied to such an action? In the pre-Erie v. Tompkins ${ }^{20}$ era it was the federal common law of unfair competition, but since 1938 the federal courts have been bound to apply the law of the state in which they sit if there is no federal question involved in the litigation. ${ }^{21}$ Three years later, the decision in Klaxon Co. v. Stentor Electric Manufacturing Co. ${ }^{22}$ extended the Erie doctrine to compel the federal courts to follow the local conflict-of-laws rules. Since most of the states have adopted the rule that the place of wrong should determine the substantive $1 a w,{ }^{23}$ in most interstate unfair-competition cases the federal court has reiterated the rule that the law to be applied is that of the place of wrong.

A case which illustrates this procedure is Adam Hat Stores, Inc. $v$. Lefco. ${ }^{24}$ The Adam Hat Company, a New York corporation, brought an action in the federal district court in Pennsylvania to restrain the defendant from selling clothes with the label, "Adams Clothes." The plaintiff's goods were sold nationally, but the defendant's operations were restricted to three stores, one each in Pennsylvania, New Jersey and Delaware. The federal court first recited the rule that the substantive law of the forum state should be applied to torts committed there and found that by Pennsylvania law the defendant's conduct was not actionable. Then, following the conflict-of-laws rule of Pennsylvania - that the place of wrong should determine the substantive law to be applied to foreign torts-the court found that neither the law of New Jersey nor of Delaware made tortious the conduct of the

\footnotetext{
${ }^{10}$ It would be to the advantage of the manufacturer to bring the action in the federal court even if he could bring it in the state courts because the federal courts are probably less sensitive to the "public policy" of the states in which they sit; also, the manufacturer could argue on appeal that the federal courts should not be bound by the local public policy. See p. 536 infra. Conceivably the action could be brought in the Supreme Court by a fair-trade state against the mail-order house-a citizen of another state-in which case the Supreme Court would have original jurisdiction under U.S. Const. Art. III, $\S 2$. There would be problems presented by this maneuver. See, generally, Missouri v. Illinois \& the Sanitary District of Chicago, 180 U.S. 208 (1901); Georgia v. Tennessee Copper Co., 206 U.S. 230 (1907); Massachusetts v. Mellon, 262 U.S. 447 (1923).

${ }^{20}$ Erie R. Co. v. Tompkins, 304 U.S. 64 (1938).

${ }^{21}$ Consult The Choice of Law in Multistate Unfair Competition: A Legal-Industrial Enigma, 60 Harv. L. Rev. 1315 (1947).

$\approx 313$ U.S. 487 (1941).

${ }^{23}$ Beale, Conflict of Laws $\$ 378$ (1935).

24134 F. 2 d 101 (C.A. 3d, 1943).
} 
defendant in those states. ${ }^{25}$ When presented with the interstate unfair-competition problem the federal courts have generally indicated a willingness to apply more than one law, ${ }^{26}$

Some courts, however, have recognized the difficulties involved in enforcing the law of the place of wrong in a multiple tort case. ${ }^{27}$ One court has observed that:

The application of the lex loci delecti is simple enough if there is a single situs of the tort against which redress is sought; but it becomes complex if not impossible when, as here, there are a multitude of states where the alleged tort is committed with conceivably conflicting laws. And one need hardly point out the probable injustice and confusion which would arise from the determination according to domestic law of a single state adroitly selected as the locus fori of issues resulting from tortious acts no one of which occurred in that state in an action whose object is injunctive relief ultimately on a nation wide pattern, and with immediate impact only in states far remote from the one whose internal law is urged as controlling. ${ }^{28}$

Another court has suggested that if the state court, rather than the federal court sitting in that state, were faced with the problem of applying the law of

${ }^{25}$ It is worth noting that what actually happened was that the court could not find any case in point in any of the three states. Believing that if the state courts had been faced with the same problem they would have followed the "general law," the court searched for a case in point and found it in a Massachusetts decision.

${ }^{3}$ Consult generally, The Choice of Law in Multistate Unfair Competition: A LegalIndustrial Enigma, 60 Harv. L. Rev. 1315 (1947). Probably because of the dearth of state unfair-competition cases in pre-Erie days, no case has been found in which a federal court has actually used more than one law in an unfair-competition case. Thus the courts have held that the law of the place of wrong was substantially the general law in: Gum v. Gumakers of America, Inc., 136 F. 2d 957 (C.A. 3d, 1943) ; SoconyVacuum Oil Co. v. Rosen, 108 F. 2d 632 (C.A. 6th, 1940); Zephyr American Corp. v. Bates Manufacturing Co., 59 F. Supp. 573 (D.C. N.J., 1945), on remand from 128 F. 2d 380 (C.A. 3d, 1942); Skinner Manufacturing Co. v. General Foods Sales Co., Inc., 52 F. Supp. 432 (D. Neb., 1943). One court has suggested that if a party wants a foreign unfair-competition law applied, he has the duty to show that it is different from the law of the forum. Federal Glass Co. v. Federal Glass Co., Inc., 104 F. Supp. 692 (D. Del., 1952). Some courts have simply applied the local law without much consideration of whether other law might not apply. Addressograph-Multigraph Corp. v. American Expansion Bolt \& Manufacturing Co., 124 F. 2d 706 (C.A. 7th, 1942); Ballard \& Ballard Co. v. Borden Co., 107 F. Supp. 41 (W.D. Ky., 1952); Independent Nail and Pack Co. v. Stronghold Screw Products, 107 F. Supp. 969 (N.D. I11., 1952), rev'd on other grounds, 205 F. 2d 921 (C.A. 7th, 1953), cert. denied, 346 U.S. 886 (1953); Triangle Publications v. New England Newspaper Publishing Co., 46 F. Supp. 198 (D. Mass., 1942).

${ }^{n}$ In the interstate libel situation the "single publication" rule has been developed which would give but one cause of action which would be determined apparently by the law of the state from which distribution takes place. Hartmann v. Time, 166 F. 2d 127 (C.A. 3d, 1948), cert. denied, 334 U.S. 838 (1948). Consult authorities cited note 17 supra. The development of a similar rule is complicated in the unfair-competition situation because injunctive relief is involved.

${ }^{23}$ Skinner Manufacturing Co. v. General Foods Sales, Inc., 52 F. Supp. 432, 439-40 (D. Neb., 1943), aff'd 143 F. 2d 895 (C.A. 8th, 1944), cert. denied 323 U.S. 766 (1944). 
its forty-seven sister states, the state court would rebel and apply only its own law; accordingly, the federal court can do the same thing and apply only the law of the forum. ${ }^{29}$

Rarely has a federal court recognized that it was faced with a conflict between the law of the forum and the law of the place of wrong concerning unfair competition. In Purcell v. Summers ${ }^{30}$ it was suggested to the court that no relief should be granted because the law of the forum would not support a cause of action for unfair competition, although the other states in which the defendant was engaged in the same conduct would grant the plaintiff relief. This is precisely the situation in which a manufacturer attempting to enforce foreign fair-trade laws in a non-fair-trade jurisdiction is placed. In the Purcell case the court disagreed with the suggested interpretation of the law of the forum (South Carolina) but in passing observed that:

Even if we were of the opinion that the decision in the state court established a rule of unfair competition at variance with the rule stated above ... it would not follow that the plaintiff would not be entitled to an injunction, but merely that the injunction should be so drawn as not to apply to activities of the defendant's limited to the State of South Carolina. . . . It would be intolerable ... [if] the determination of the controversy ... should depend upon the rule prevailing in one of the states, simply because a suit with relation thereto happened to be tried there. And this would be particularly unfortunate if the rule prevailing in such state was at variance with the rule prevailing in the others. Unfair competition is a tort governed by the law of the state where it occurs. If it occurs in a number of states it must be dealt with according to their laws; and injunction against conduct constituting unfair competition in a number of states may not be denied merely because under the law of another state it is not recognized as unfair. ${ }^{31}$

This accumulation of dicta suggests that the law to be applied by a court in the non-fair-trade jurisdiction is the foreign fair-trade law of the place of wrong. But the rule which would apply the law of the place of wrong is subject to an elusive exception: if the foreign law is contrary to the public policy of

\footnotetext{
29 The state courts would have "the robust common sense to avoid writing opinions and entering decrees adapted with academic nicety to the vagaries of forty-eight states. And until Massachusetts adopts a checker-board jurisprudence, the Klaxon case does not require this court to do so." National Fruit Product Co. v. Dwinell-Wright Co., 47 F. Supp. 499, 504 (D. Mass., 1942), aff'd 140 F. 2d 618 (C.A. 1st, 1944). This result could be avoided if the fair-trade action were brought by $a$ wholesaler whose activities were limited to a single fair-trade jurisdiction, rather than by the manufacturer whose interests extend into every state. This could be done since the statutory tort of unfair competition gives a cause of action to anyone injured by violation of the price policy.

${ }^{30} 145$ F. 2d 979 (C.A. 4th, 1944).

${ }^{32}$ Ibid., at 989 . When Judge Parker referred to the rule that "a tort is governed by the law of the state where it occurs," he was presumably applying the conflicts rule of the state of the forum. A case involving exactly the opposite situation-one jurisdiction which would grant relief with many, including the forum, that would not-led to the contrary result: R.C.A. Mfg. Co. v. Whiteman, 114 F. 2d 86 (C.A. 2d, 1940).
} 
the forum, it will not be enforced. ${ }^{32}$ Federal courts, bound to follow the law of the state in which they sit, should not hear a foreign cause of action if the public policy of the forum state is contrary to the foreign law. Thus the Supreme Court has said:

Rights acquired by contract outside a state are enforced within a state, certainly where its own citizens are concerned; but that principle excepts claimed rights so contrary to the law of the forum as to subvert the forum's view of public policy. ${ }^{33}$

The Restatement of Conflict of Laws and most of the commentators have adopted the view that a foreign cause of action should be barred only when enforcing the right would violate a strong public policy of the forum. ${ }^{34}$ The leading case in support of this view is Loucks v. Standard Oil Co., ${ }^{35}$ in which Judge Cardozo said:

If aid is to be withheld here, it must be because the cause of action offends our sense of justice or menaces the public welfare. ... Our own scheme of legislation may be different. We may even have no legislation on the subject. That is not enough to show that public policy forbids us to enforce the foreign right. . . We are not so provincial as to say that every solution of a problem is wrong because we deal with it otherwise at home. .. The courts are not free to refuse to enforce a foreign right at the pleasure of the judges, to suit the individual notion of expediency or fairness. They do not close their doors unless help would violate some fundamental principle of justice, some prevalent conception of good morals, some deep-rooted tradition of the common weal. ${ }^{36}$

While this narrow view of the limitation of public policy has not been explicitly rejected, it has not fared altogether well in the courts. The difficulty lies basically in measuring public policy. Lacking any other means of discovering the public policy of a state, the courts have turned to the state statutes and decisions. Having done this, they have found it a practical impossibility to distinguish between those statutes and court opinions which express a strong public policy and those whose basic motivation is less powerful..$^{37}$

An examination of the federal cases reveals that their primary guide to public policy is the state legislature. If there is a statute which will not allow the action in the state court, the federal court sitting in that state will decline to hear the

sest., Conflict of Laws $\$ 612$ (1934).

${ }^{32}$ Griffin v. McCoach, 313 U.S. 498, 506 (1941).

sk Rest., Conflict of Laws $\$ 612$, Comment c (1934); Beale, Conflict of Laws $\$ 612.1$ (1935); Goodrich, Conflict of Laws $\$ 11$ (1935). Compare Nussbaum, Public Policy and the Political Crisis in the Conflict of Laws, 49 Yale L. J. 1027 (1940).

${ }^{35} 224$ N.Y. 99, 120 N.E. 198 (1918).

${ }^{30}$ Ibid., at 110-11, 201-2.

${ }^{37}$ But see Crouch, J., minority opinion in Mertz v. Mertz, 271 N.Y. 466, 475, 3 N.E. 2d 597, 600 (1936), where he expressed the opinion that there could be no great difference in public policy between the states. 
case because it would be contrary to the public policy of the forum. ${ }^{38}$ On the other hand, when the two jurisdictions have statutes which are substantially similar or attempt to achieve the same end, the federal court will usually hear the action even though there is a conflict between the specific provisions. ${ }^{39} \mathrm{It}$ is also true that absence of a statute in the forum state similar to the one which is the basis for the foreign cause of action will not necessarily bar the plaintiff. ${ }^{40}$

Where a manufacturer is seeking to enforce a fair-trade law in a non-fairtrade jurisdiction, there may be state antitrust statutes which declare a public policy contrary to such an action. Of the three states which have not passed fair-trade laws, two-Missouri ${ }^{41}$ and Texas ${ }^{42}$-have antitrust laws which would make fair-trade contracts void as contrary to public policy. If an action based on such a contract were brought in a Missouri or Texas court, it might refuse to enforce the foreign cause of action. Unless the federal court is prepared to abandon the standard which has been used thus far in determining public policy, it would probably rule that a manufacturer could not enter those states and seek to restrain price-cutting.

The same result could occur in the states which have found the nonsigner

${ }^{38}$ Thus when a Mississippi citizen brought a libel action in Georgia against a Georgia newspaper, the federal court refused to hear the case because a Georgia statute provided that no libel action could be brought without giving the publisher notice and an opportunity to retract. Tademy v. Scott, 157 F. 2d 826 (C.A. 5th, 1946). Similarly, foreign causes of action for breach of promise to marry have been denied by federal courts sitting in Massachusetts [Fahy v. Lloyd, 57 F. Supp. 156 (D. Mass., 1944)], New York [O'Connor v. Johnson, 74 F. Supp. 370 (W.D. N.Y., 1947)], and Pennsylvania [A.B. v. C.D., 36 F. Supp. 85 (E.D. Pa., 1940)], because statutes in those states had abolished the cause of action. An Illinois real estate man was unable to collect in a federal court located in Wisconsin his commission for a sale of Wisconsin land, even though the contract was made in Illinois, because Wisconsin had a statute requiring real estate agents to register before they could sue for their commissions. Reed v. Kelly, 177 F. 2d 473 (C.A. 7th, 1949). An action to enjoin a former employee, a Michigan citizen, from seeking employment with a competitor of the plaintiff was denied by a federal court in Michigan despite the fact that the contract was made in Mlinois, because a Michigan statute made such contracts void. May v. Mulligan, 36 F. Supp. 596 (W.D. Mich., 1939). Cf. Matthews Conveyer Co. v. Palmer-Bee Co., 135 F. 2d 73 (C.A. 6th, 1943). Actions on contracts which Missouri and New York statutes would make champertous were denied by federal courts sitting in those states though the contracts were presumably valid in the states in which they were made. Jamison Coal and Coke Co. v. Goltra, 143 F. 2d 889, 895 (C.A. 8th, 1944); Transbel Investment Co. v. Roth, 36 F. Supp. 396 (S.D. N.Y., 1940),

${ }^{30}$ Kroger Grocery and Baking Co. v. Reddin, 128 F. 2 d 787 (C.A. 8th, 1942); Indemnity Insurance Co. v. Pan American Airways, 57 F. Supp. 980 (S.D. N.Y., 1944). But cf. Slater v. Mexican National R. Co., 194 U.S. 120 (1904).

${ }^{60}$ James-Dickinson Co. v. Harry, 273 U.S. 119 (1927).

1 Mo. Ann. Stat. (Vernon, 1952) $\$ 416.020$.

Texas Rev. Civ. Stat. (1951) Art. 7426, 7429, 7437. The same is true of the District of Columbia, since Congress has not passed a fair-trade law there and, accordingly, the antitrust laws apply. However, the Miller-Tydings Amendment and the McGuire Amendment would probably be sufficient to convince a D.C. court that the District had no strong public policy against fair-trade laws. 
provision in the fair-trade laws violative of their state constitutions. ${ }^{43}$ In a sense this would seem to represent a higher form of public policy than a mere anti-monopoly act, but if the Florida experience is at all typical, ${ }^{44}$ the constitutionality of these fair-trade laws represents a continuing battle between the legislature and the courts. It might be suggested that since "half" of the state's public policy is in favor of fair trade, the public policy of the forum has not been finally expressed as against resale price maintenance.

The mere allegation of a sharp difference between the statutes of the forum and the foreign state would not necessarily be enough to convince the court that the foreign law ought not to be enforced; the mail-order house would also have to establish that the non-fair-trade state's policy would be adversely affected by applying the foreign law. This question goes directly. to the policy behind the statute which is urged as barring the foreign cause of action. ${ }^{45}$ Thus when a federal court sitting in New York declined to hear

${ }^{4}$ Arkansas: a lower court has held the Fair Trade Act unconstitutional. Union Carbide and Carbon Corp. v. White River Distributors, Inc., $1954 \mathrm{CCH}$ Trade Cases $\$ 67,781$ (Ark. Chan. Ct., 1954). Florida: see note 44 infra. Michigan: Shakespeare Co. v. Lippman's Tool Shop Sporting Goods Co., 334 Mich. 109, 54 N.W. 2d 268 (1952). Minnesota: the Attorney General has expressed the belief that the Fair Trade law is valid, Opinion of the Attorney General of Minnesota, $1952 \mathrm{CCH}$ Trade Cases 967,391 , on the theory that the Minnesota Supreme Court's opinion in Calvert Distillers Corp. v. Sachs, 234 Minn. 303, 48 N.W. 531 (1951), was based on the Schwegmann case which had been overruled by the McGuire Amendment. Nebraska: General Electric Co. v. J. L. Brandeis and Sons, 1954 CCH Trade Cases I 67,682. (Dist. Ct., Neb., 1954).

"The Florida situation is that at the moment fair trade is unenforceable. The fight between the legislature and the court started in 1937 when the legislature first passed a fair-trade statute. The court struck it down as unconstitutional because the title to the act was misleading. Bristol-Myers Co. v. Webb's Cut Rate Drug Co., 137 Fla. 508, 188 So. 91 (1939). The legislature repaired this defect, but the same act was again held unconstitutional, this time because the nonsigner clause was an unwarranted exercise of the police power, considering the economic situation, and it was an unreasonable restriction on the right to own and dispose of property. Liquor Store, Inc. v. Continental Distilling Corp., 40 So. 2d 371 (1949). In 1949 the legislature added to the act what it termed "Findings of Fact" which in effect said that fair trade would serve the public interest and general welfare, and prevent monopoly, and that the statute was a lawful exercise of the police power. But the Florida Supreme Court declined to follow these findings of fact, and again held the act unconsitutional, Seagram-Distillers Corp. v. Ben Greene, Inc., 54 So. 2d 235 (1951), partially on the grounds of the U.S. Supreme Court's decision in Schwegmann Bros. v. Calvert Distillers Corp., 341 U.S. 384 (1951). After the passage of the McGuire Amendment the legisiature finally won a round in the courts on the theory that the Seagram case rested on the Schwegmann decision which had been overruled by the McGuire Amendment. Sunbeam Corp. v. Chase \& Sherman, Inc., 1953 CCH Trade Cases I 67,524 (C.C. Fla., 1953). However, the Florida Supreme Court refused to follow that construction of its previous decision and again held the act unconstitutional as an unwarranted exercise of the police power in Miles Laboratories Inc. v. Ekherd, 73 So. 2d 680 (1954).

w The necessity of establishing that the public policy of the forum is involved in a case before it can be urged as a bar to a foreign cause of action can be seen in the language of the Supreme Court in cases which came before the Court in the thirties. The Court found the interests of the forum state unaffected in Home Life Insurance Co. v. Dick, 281 U.S. 397 (1930), in which Brandeis, J., said, "Dick urges . . . that a 
a foreign breach-of-promise action because the New York legislature had abolished the cause of action, it was justified in so doing because the policy of that statute was to protect the state's courts from being used as tools of extortion. ${ }^{46}$ Such a policy would be subverted by hearing either a local or a foreign cause of action.

In this case, the statute which declares the public policy of the non-fairtrade state is an antitrust statute. If the policy behind that law is considered as solely for the benefit of consumers, it would be difficult to spell out an interest which the non-fair-trade state has that would justify excluding the foreign fair-trade action. The relief which the manufacturer would seek would relate only to foreign consumers. The people of the non-fair-trade state would still be able to buy fair-traded items at prices independently determined by their local merchants. If, however, the policy of antitrust legislation is broader and encompasses the sweep of free-enterprise thinking, it is conceivable that the non-fair-trade state's policy would be adversely affected by enforcing the foreign fair-trade law. The point to be emphasized would

state may properly refuse to recognize foreign rights which violate . . . its laws or public policy. ... We need not consider how far the state ... may go in refusing to lend the aid of its courts to the enforcernent of rights acquired outside its borders. It may not abrogate the rights of parties ... having no relation to anything done or to be done within them." Ibid., at 410. Later Brandeis spoke for the Court in Bradford Electric Light Co. v. Clapper, 286 U.S. 145 (1932), coming to the same conclusion in these words: "[T] $]$ here is no adequate basis for the lower court's conclusion that to deny recovery would be obnoxious to the public policy of New Hampshire. No decision . . . has been cited indicating that recognition of the Vermont statute would be regarded in New Hampshire as prejudicial to the interests of its citizens. . . . Nor does sufficient reason appear why it should be so regarded. The interest of New Hampshire was only casual. Leon Clapper was not a resident there. He was not continuously employed there. So far as appears he had no dependent there. It is difficult to see how the State's interest would be subverted, under such circumstances, by burdening its courts with this litigation." Ibid., at 161-62. The Court came to the opposite conclusion and allowed a state court to decline to recognize a foreign statute in Alaska Packers Association v. Industrial Accident Commission, 294 U.S. 532 (1935), in which Justice Stone said that the forum state "had a legitimate public interest in controlling and regulating this employer-employee relationship in such fashion as to impose a liability upon the employer for an injury suffered by the employee, and in providing a remedy available to him in California." Ibid., at 542-43. "[T]here are some limitations upon the extent to which a state will be required by the full faith and credit clause to enforce even the judgment of another state, in contravention of its own statutes or policy.... [I]t is unavoidable that this Court determine for itself the extent to which the statute of one state may qualify or deny rights asserted under the statute of another." Tbid., at 546-47. "The conflict is to be resolved . . . by appraising the governmental interests of each jurisdiction, and turning the scale of decision according to their weight." Ibid., at 547. "Without a remedy in California, they would be remediless, and there was the danger that they might become public charges, both matters of grave concern to the State." Ibid., at 542. Accord: Pacific Employers Insurance Co. v. Industrial Accident Commission, 306 U.S. 493 (1939).

${ }^{16}$ O'Connor v. Johnson, 74 F. Supp. 370 (W.D. N.Y., 1947). Accord: Tademy v. Scott, 157 F. 2d 826 (C.A. 5th, 1946); Fahy v. Lloyd, 57 F. Supp. 156 (D. Mass., 1944). 
be that the mail-order house is incorporated and doing all of its business within the non-fair-trade state. Thus it could be argued that the policy of antitrust acts is not only to provide consumers with the benefits of active competition, but also to provide an unconscious control over the privately owned business structure of the state through price competition. To compel the local mail-order house to obey foreign fair-trade price lists would alter the internal business structure of the state. While in essence the mail-order house is an export firm, this would not distinguish it because many businesses within the non-fair-trade state would be engaged in interstate commerce. Under this conception of the policy of state antitrust laws, the non-fair-trade state has a legitimate interest in seeing that businesses within the state are not discouraged by the imposition of a foreign law contrary to the competitive norm established by the antitrust law.

If a federal court should decline to enforce the foreign cause of action because the public policy of the state in which it sits is contrary to the theory of resale price maintenance, the Supreme Court will be confronted with a difficult problem. States' rights would appear on both sides of the argument. The mail-order house could argue with force that each state ought to be allowed to determine its own public policy, unaffected by the policy of its sister states. On the other side the manufacturer could argue that the public policy of one state ought not to be allowed to undermine the legislative policies of forty-five other states.

The Supreme Court could justify the enforcement of a foreign fair-trade law in a non-fair-trade state in at least two ways, both of which seem improbable. The Court could (1) expand the concept of full faith and credit to require that all states apply foreign law to foreign wrongs regardless of the public policy of the forum, or (2) overrule the Griffin v. McCoach ${ }^{47}$ precedent and hold that federal courts are not bound by the public policy of the state in which they sit.

The scope of the full faith and credit clause in the Constitution is possibly the most uncertain area in constitutional law today. ${ }^{48}$ The Court has recently indicated that there are some limitations on what state legislatures can do in barring foreign causes of action. In Hughes v. Fetter ${ }^{49}$ the Supreme Court held unconstitutional a Wisconsin statute providing that no actions could be brought in that state's courts under foreign wrongful-death statutes. The action was between Wisconsin citizens, but the accident occurred in Illinois. Following the legislature's instructions, the Wisconsin court had held that the public policy of the state prevented its hearing the action. The Supreme Court, split five to four, appeared to hold that despite the legisla-

${ }^{47} 313$ U.S. 498 (1941).

${ }^{48}$ Consult Cheatham, Federal Control of Conflict of Laws, 6 Vand. L. Rev. 581 (1953).

341 U.S. 609 (1951). 
ture's words there was no strong public policy in Wisconsin against entertaining actions under the Illinois wrongful-death act. This may be another application of the rule requiring that the state must have a reasonable interest in the case before it can justifiably bar a foreign cause of action on the ground of public policy. ${ }^{50}$ In any event, the difference of views within the Court apparently centered around the question of whether Wisconsin's policy was strong enough to bar the action. All of the justices agreed that full faith and credit did not always compel the state court to apply a foreign law.

The key point in the fair-trade situation is the argument that the policy of the antitrust law of the non-fair-trade state would be subverted by enforcement of the foreign fair-trade law; once the Court accepts that argument, it will probably have to put foreign statutes in the same class as foreign judgments in order to reach the result that the non-fair-trade state would have to enforce the foreign fair-trade law..$^{51}$ In view of the strong dicta in all the opinions in Hughes v. Fetter ${ }^{52}$ that situations could arise where a state might properly bar a foreign cause of action because of its public policy, it seems most unlikely that the Court would be willing to spell out such a constitutional obligation to enforce foreign statutes from the full faith and credit clause.

Short of this the Court might still require the non-fair-trade jurisdiction to enforce the fair-trade law of another state by following the suggestion of the late Justice Jackson in his specially concurring opinion in First $\mathrm{Na}$ tional Bank of Chicago v. United Air Lines, Inc., ${ }^{53}$ a case similar in its facts to Hughes v. Fetter. ${ }^{54}$ Both cases concerned substantially the same provision of a wrongful-death statute, but in the Air Lines case the action was brought in a federal court rather than a state court. The defendant contended that the federal court could not hear the case because: (1) the forum state's statute prohibited actions brought for foreign deaths, and (2) this prohibition also applied to a federal court sitting in that state. ${ }^{55}$ The majority of the Supreme Court struck down the Illinois statute as violative of full faith and credit, but Justice Jackson suggested that,

Since as a matter of constitutional provision liability for this alleged tort must be adjudged under Utah law and the case being within the statutory jurisdiction of the District Court, it may ascertain and apply the law of Utah without straining it through the Illinois sieve. ${ }^{56}$

${ }^{50}$ See cases cited note 45 supra.

51 This was advocated by Reese, Full Faith and Credit to Statutes: the Defense of Public Policy, 19 U. of Chi. L. Rev. 339 (1952). Consult also Crosskey, Politics and the Constitution in the History of the United States 542-57 (1953).
${ }^{52} 341$ U.S. 609 (1951).
341 U.S. 609 (1951).
${ }^{\star 3} 342$ U.S. 396 (1952).
屯s Angel v. Bullington, 330 U.S. 183 (1947).

${ }^{80}$ First National Bank of Chicago v. United Air Lines, Inc., 342 U.S. 396, 401 (1952). 
In other words, the federal courts would not be bound to follow the public policy of the states in which they sit. This would in part represent a retreat from the reasoning of Erie $v$. Tompkins; conceivably the accident of diversity of citizenship might provide one litigant with relief in a federal court which would be denied another in a neighboring state court though the facts were identical. On the other hand, the chances of a frequent difference in result appear slight. ${ }^{57}$ Jackson's suggestion would at least temporarily provide relief from polarity of result-it would preserve to the states the power to determine their own public policies, and at the same time affirm the policy that at least in the federal courts relief will be provided no matter where the action is brought or where the wrong occurred.

It seems more likely that the Court would decide the action brought by the foreign manufacturer along traditional public-policy lines with the result that the manufacturer could not obtain injunctive relief against the mailorder house (assuming, of course, that the Court accepted the suggested theory that the forum state has a justification for asserting its non-fair-trade public policy). ${ }^{58}$ This would be a difficult result to reach on the facts. The mail-order house was probably created with the single object of avoiding state laws and gaining an economic advantage thereby. If the Court approves such dubious conduct, it might destroy fair trade. The possibility of the end of fair trade is suggested by the few cases in which the courts in fair-trade jurisdictions have exercised equitable discretion and declined to give a manufacturer an injunction against a clear violation of the fair-trade agreement because the violator was merely meeting the competition presented by other violators. ${ }^{59}$ Thus far the courts have been fairly strict in this matter, allowing the violator to escape only when there was strong evidence of bad faith on the part of the manufacturer or where it seemed evident that the manufacturer had waived his right to a fair-trade price policy. ${ }^{60} \mathrm{It}$ is impossible to predict how long the chancellor's discretion could hold out against the argument that the foreign mail-order house is destroying the price policy and that therefore violators inside the fair-trade jurisdiction should be free

\footnotetext{
${ }^{52}$ But it would happen occasionally. See, for an example, Doggrell v. Great Southern Box Co., Inc. of Miss., 206 F. $2 d 671$ (C.A. 6th, 1953), and Paper Products Co. v. Doggrell, 195 Tenn. 581, 261 S.W. 2d 127 (1953).

${ }^{58}$ See page 534 supra.

${ }^{60}$ Calvert Distillers Corp. v. Nussbaum Liquor Store, Inc., 166 Misc. 342, 2 N.Y.S. 2d 320 (S. Ct., 1938) ; General Electric Co. v. R. H. Macy \& Co., 199 Misc. 87, 103 N.Y.S. 2d 440 (S. Ct., 1951), and authorities cited therein. Consult also $1 \mathrm{CCH}$ Trade Reg. Rep. \{f 3448, 3440, 3452; and 163 A.L.R. 889 (1946).

${ }^{60}$ This defense is basically the equitable doctrine of clean hands. To apply it where the manufacturer was unable to prevent the price-cutting, suggested in the text as a possibility, would expand the conception of the "meeting competition" defense far beyond its present scope to include situations where the enforcer was in no sense at fault.
} 
to set their own prices. The Supreme Court would have to consider the possibility that courts in fair-trade jurisdictions might refuse to enforce their own laws because of the mail-order house's activities.

Before the Court arrives at a consideration of these last problems, it will have to be persuaded that a tort has been committed in a fair-trade jurisdiction; that the public policy of the non-fair-trade state is against fair-trade actions; and that enforcing the foreign fair-trade laws will in some sense subvert that public policy. Should the Court decide that the public policy of the forum bars the manufacturer's fair-trade action, the result will not be surprising. Congress has full power to legislate with regard to interstate commerce, but with fair trade it has chosen to abdicate that power to the states. It is not particularly shocking that the full faith and credit clause will not do what the commerce clause can do.

\section{DAMAGES FOR THE WRONGFUL DEATH OF CHILDREN}

The death of a child is the greatest of all losses-impossible of compensation-and yet at the same time an economic saving to the family involved. This situation poses a perplexing problem for our tort law by placing a great strain on the avowed principle that damages should be strictly compensatory in nature. Significant changes in the economic and social environment since the passage of Lord Campbell's Act in 1846 have made more acute the question whether substantial damages should be awarded for the wrongful death of a child. ${ }^{1}$ It is the purpose of this comment to indicate the difficulties involved in existing legal doctrines in the child death area, the economic factors affecting the "value" of the child to the family, and, finally, possible alternatives to present methods of compensation.

\section{I}

At common law there was no action for wrongful death. ${ }^{2}$ For various reasons this result was thought to be unsatisfactory ${ }^{3}$ consequently, statutes were

${ }^{1}$ The number of persons affected by this area of the law is indicated by the fact that 12,300 persons under twenty-four years of age died in 1952 in motor vehicle accidents alone where, in all probability, a large portion of the deaths would be actionable. National Safety Council, Accident Facts 59 (1953 ed.). In 1950, 22,453 persons under twenty-four years of age died from accidents of all types. Ibid., at 91 . See also Dublin, Health Progress 1936 to 1945, at 95 et seq. (1948).

${ }^{2}$ In "a civil court, the death of a human could not be complained of as an injury." Baker v. Bolton, 2 Rolle's Abridgement 575, placita 2 and 3 (1808). For a discussion of the common-law doctrine and early American cases, see Tiffany, Death by WrongfuI Act $\$ \$ 1-3,11$ (2d ed., 1913); Voss, The Recovery of Damages for Wrongful Death at Common Law, at Civil Law, and in Louisiana, 6 Tulane L. Rev. 201, 203 et seq. (1932).

${ }^{3}$ The main reason was the inequity of allowing recovery where plaintiff is almost killed but allowing no civil action where the wrongdoer commits the supposedly more serious offense of causing death. 